\title{
EFEKTIVITAS PENGELOLAAN ALOKASI DANA DESA \\ (Studi Kasus Pada Desa Tegal Arum Kecamatan Mranggen \\ Kabupaten Demak)
}

\author{
Moeljono $^{1}$ \\ Willyanto Kartiko Kusumo ${ }^{2}$ \\ sastro@usm.ac.id ${ }^{l}$ \\ willyanto@usm.ac.id ${ }^{2}$
}

Fakultas Ekonomi, Universitas Semarang,

Diterima: Mei 2019, Disetujui: Juni 2019, Dipublikasikan: Juli 2019

\begin{abstract}
This article aims to determine the effectiveness of village fund allocation Management. The data collection methods used in this study are literature studies and field studies. The observation results were analyzed through a descriptive analysis method describing how the effectiveness of village fund allocation management is effective. The observation shows that the effectiveness of village fund allocation management, where there are three phases of planning, implementation and supervision. Administratively, the three phases can be completed properly and fulfill the effective principles in the indichatory of information transparency to the public.
\end{abstract}

Keywords: effectiveness, management of village funds allocation.

\begin{abstract}
Abstrak
Artikel ini bertujuan untuk mengetahui Efektifitas Pengelolaan Alokasi Dana Desa (ADD). Metode pengumpulan data yang digunakan dalam penelitian ini adalah studi kepustakaan dan studi lapangan. Selanjutnya hasil pengamatan dianalisis melalui metode analisis deskriptif dimana menggambarkan bagaiman tingkat efektifitas pengelolaan alokasi dana desa. Hasil pengamatan menunjukan bahwa Efektifitas Pengelolaan Alokasi Dana Desa, dimana ada tiga tahap yakni perencanaan, pelaksanaan dan
\end{abstract}


pengawasan. Secara administrasi ketiga tahap tersebut dapat terselesaikan dengan baik dan memenuhi prinsip efektif yang di indikatori adanya tranparansi informasi kepada masyarakat. .

Kata Kunci: Efektivitas, Pengelolaan Alokasi Dana Desa, Pembangunan.

\section{PENDAHULUAN}

\section{Latar Belakang}

Kajian tentang Dana Desa sangat menarik untuk dibahas seiring bertambahnya alokasi dan aparat desa yang terkena kasus masalah dana desa, dan harus berurusan dengan penegak hukum. Alokasi dana desa sejak dikucurkan pertama kali ditahun 2015 sampai sekarang terus meningkat.

Desa Tegal Arum, Kecamatan Mranggen Kabupaten Demak merupakan salah satu desa yang menerima kucuran Dana Desa dari APBN di Tahun Anggaran 2018 menerima sebesar Rp 1.012.825.000, jumlah yang terus meningkat dari tahun ketahun berikut data ADD tahun 2017 sampai dengan 2019

Tabel 1

Jumlah Alokasi Dana Desa

Desa Tegalarum Kecamatan Mranggen Kabupaten

Demak

\begin{tabular}{ccc}
\hline No & Tahun & Jumlah Alokasi Dana Desa \\
\hline 1 & 2017 & Rp 800000.000 \\
2 & 2018 & Rp 1.012 .000 .000 \\
3 & 2019 & Rp 1.012 .825 .000 \\
\hline
\end{tabular}

Sumber : Dokumen Desa Tegalarum (2019)

Tujuan utama adanya dana desa diharapkan dapat menjadi daya ungkit bagi peningkatan kapasitas dan kesejahteraan masyarakat desa. Walaupun usaha untuk meningkatkan kesejahteraan telah dilakukan sejak lama. Proses pembangunan 
yang melibatkan masyarakat yang bersifat Bottom Up dimulai sejak di sahkannya UU tentang UU Onotomi Daerah, namun proses tersebut terus mencipkan rajaraja kecil di daerah dan menciptakan gap kemiskinan antara perdesaan dan perkotaan. Ketimpangan kemiskinan di Indonesia terlihat pada gambar 1.

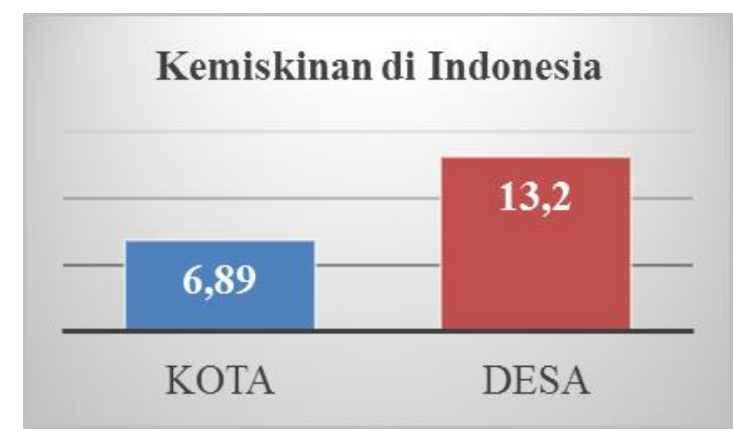

Gambar 1.

Ketimpangan Kemiskinan di Indonesia

Sumber: BPS (September 2018)

Dana desa merupakan implementasi dari UU 32/ 2004 tentang Pemerintahan Daerah dan PP 6/ 2014 tentang Desa, dan dilaksanakan pada 1 Januari 2015. Dana desa merupakan legal formal pengakuan dari pemerintah akan keberadaan desa, sehingga desa merupakan satu kesatuan dari sistem pemerintahan, sebagai kesatuan masyarakat hukum yang memiliki batas wilayah dan berwenang untuk mengatur dan mengurus urusan pemerintahan, kepentingan masyarakat atas dasar prakarsa masyarakat yang diakui dan dihormati dalam sistem pemerintahan. Konsekuensi logis dari pelaksanaan pemerintahan adalah adanya dana untuk operasional dan pembangunan desa.

Berdasarkan ketentuan ini desa mempunyai kewenangan untuk Penyusunan rencana pembangunan desa dilakukan berdasarkan prinsip perencanaan dari bawah, dari, oleh dan untuk rakyat, dilakukan dengan prnisip efisien dan efektif. Apabila dana tersebut dikelola dengan baik, maka 
kesejahteraan masyarakat akan lebih terasa dalam pembangunan fisik maupun pembangunan non fisik yang menjembatani kelangsungan kehidupan masyarakat.

\section{Pertanyaan Penulisan}

Pertanyaan yang menjadi dasar pada penulisan ini adalah "Bagaimana Efektivitas Pengelolaan Alokasi Dana Desa di Desa Tegal Arum, Kecamatan Mranggen Kabupaten Demak.

\section{Tujuan Penulisan}

Berdasarkan pertanyaan penulisan tujuannya adalah untuk mengetahui efektivitas pengelolaan Alokasi Dana Desa, pada Desa Tegal Arum, Kecamatan Mranggen, Kabupaten Demak.

\section{KAJIAN PUSTAKA}

\section{Konsep Efektivitas}

Efektivitas berasal dari kata efektif yang mengandung pengertian dicapainya tujuan yang telah ditetapkan. Efektivitas selalu terkait dengan hubungan antara hasil yang diharapkan dengan hasil yang sesungguhnya dicapai. Efektivitas dapat dilihat dari berbagai sudut pandang (view point) dan dapat dinilai dengan berbagai cara dan mempunyai kaitan yang erat dengan efisiensi. Menurut The Liang Gie (2002), efektivitas adalah keadaan atau kemampuan suatu kerja yang dilaksanakan oleh manusia untuk memberikan hasil guna yang diharapkan. Sedangkan Gibson (1995) mengemukakan bahwa efektivitas adalah konteks perilaku organisasi yang merupakan hubungan antar produksi, kualitas, efisiensi, fleksibilitas, kepuasan, sifat keunggulan dan pengembangan.

\section{Konsep Pengelolaan}

Balderton (dalam Adisasmita, 2011:21) istilah pengelolaan sama dengan manajemen yaitu menggerakan, mengorganisasikan, dan mengarahkan usaha 
manusia untuk memanfaatkan secara efektif material dan fasilitas untuk mencapai suatu tujuan.

Selanjutnya Adisasmita (2011:22) mengemukakan, "Pengelolaan bukan hanya melaksanakan suatu kegiatan, akan tetapi merupakan rangkaian kegiatan yang meliputi fungsi-fungsi manajemen, seperti perencanaan, pelaksanaan, dan pengawasan untuk mencapai tujuan secara efektif dan efisien."

\section{Alokasi Dana Desa}

Alokasi Dana Desa adalah dana yang bersumber dari APBN melalui APBD Kabupaten/kota, dengan tujuan pemerataan kemampuan keuangan antar desa untuk mendanai kebutuhan desa dalam rangka penyelenggaraan pemerintahan dan pelaksanaan pembangunan serta pelayanan masyarakat. Alokasi dana desa bagian keuangan desa diperoleh dari bagi hasil pajak daerah dan bagian dari dan perimbangan keuangan pusat dan daerah yang di terima oleh kabupaten.

\section{Konsep Pembangunan}

Aprillia (2014:1) menyatakan, pembangunan merupakan upaya-upaya untuk tercapainya kenaikan kesejahteraan hidup bagi setiap invidu maupun masyarkat luas. Aprillia (2014:1) mendefinisikan pembangunan sebagai segala upaya yang terus menerus di tujukan untuk memperbaiki kehidupan masyarakat dan bangsa yang belum baik, atau untuk memperbaiki kehidupan yang sudah baik menjadi lebih baik.

Todaro (2000:20), mendefinisikan pembangunan merupakan suatu proses multidemensi yang meliputi perubahan struktur sosial, sikap masyarakat, lembaga-lembaga nasional, sekaligus peningkatan pertumbuhan ekonomi, pengurangan kesenjagan dan pemberantasan kemiskinan.

\section{Efektivitas Pengalokasian Dana Desa (ADD)}

Osborne dan Gaebler (1997), efisiensi adalah ukuran berapa banyak biaya yang dikeluarkan untuk per unit output, sedangkan efektivitas adalah ukuran kualitas output itu. Ketika mengukur efisiensi, harus diketahui berapa banyak 
biaya yang harus ditanggung untuk mencapai suatu output tertentu. Ketika mengukur efektivitas harus diketahui apakah investasi tersebut dapat berguna. Efisiensi dan efektivitas merupakan hal penting, tetapi ketika organisasi publik mulai mengukur kinerja, seringkali hanya mengukur tingkat efisiensi saja. Sedangkan Efektivitas pelaksanaan program lazimnya berkaitan dengan upaya pengukuran ataupun penilaian terhadap sejauh mana tercapainya tujuan (Dunn, 3003:429).

\section{Konsep Anggaran}

Anggaran juga dapat diartikan sebagai istilah perencanaan untuk pengendalian laba menyeluruh dapat didefenisikan secara luas sebagai suatu anggaran sistematis dan formal untuk perencanaan, pengkoordinasian dan pengendalian tanggung jawab manajemen (Welsch, 2000).

Nafarin (2000), “anggaran merupakan rencana tertulis mengenai kegiatan suatu organisasi yang dinyatakan secara kuantitatif untuk jangka waktu tertentu dan umumnya dinyatakan dalam satuan uang, tetapi dapat juga dinyatakan dalam satuan barang maupun jasa”. Tidak setiap rencana kerja organisasi dapat disebut sebagai anggaran. Oleh karena itu anggaran memiliki beberapa ciri khusus yang membedakan dengan sekedar rencana (Rudianto, 2006).

\section{Kerangka Pemikiran}

Efektivitas proses pengelolaan alokasi dana desa dilihat dari perencanaan, pelaksanaan dan pegawasan. (Adisasmita, 2011:22). Sedangkan peningkatan pelaksanaan pembangunan menurut Bachtiar Effendi (2002, 114) adalah pembangunan fisik dan pembangunan non fisik

\section{METODE PENELITIAN}

\section{Lokasi dan Waktu Penelitian}

Lokasi pengamatan di laksanakan di Desa Tegal Arum, Kecamatan Mranggen, Kabupaten Demak, yang melaksanakan program Pengalokasian 
Alokasi Dana Desa (ADD). Waktu pengamatan dilaksanakan selama bulan April 2018.

\section{Informan Penelitian}

Sebagai subyek informasi penulisan ini adalah seluruh perangkat desan ditambah dengan tokoh masyarakat desa Tegal Arum, yang berjumlah 6 orang ditetapkan sebagai informan yaitu terdiri dari:

\section{Tabel 2}

Daftar Informan

\begin{tabular}{clll}
\hline No & \multicolumn{1}{c}{ Jabatan } & \multicolumn{1}{c}{ Nama } & Gender \\
\hline 1 & Kepala Desa & Ali Khadirin & Pria \\
2 & Sekretaris Desa (plt) & H. Mashudi & Pria \\
3 & Kasi Pemerintahan dan Operator & Hj, Murtini SH & Wanita \\
& Desa & & \\
4 & BPD & H. Moh. Sarmin. M. Pria & \\
& & Si & Pria \\
6 & Tokoh Masyarakat & Kholiq & Pria \\
\hline
\end{tabular}

Sumber : Data Desa Tegal Arum (2019)

\section{Jenis dan Sumber Data}

Pada penulisan ini menggunankan data sebagai berikut:

\section{Data Primer}

Data primer merupakan data yang diperoleh secara langsung dari lokasi penelitian melalui wawancara dengan informan yang berkaitan dengan pengelolaan alokasi dana desa dan juga melalui observasi atau pengamatan langsung terhadap objek. 


\section{Data Sekunder}

Data sekunder merupakan data yang diperoleh secara tidak langsung dari objek, antara lain studi literatur, kepustakaan dan arsip/laporan seperti: Laporan-laporan periodik, laporan tahunan dan dokumen-dokumen dari kantor desa.

\section{Teknik Pengumpulan Data}

Tehnik pengumpulan data pada penulisan kali ini adalah:

1. Studi kepustakaan yaitu pengumpulan data melalui bahan-bahan yang tertulis yang relevan dengan penelitian ini, seperti literatur dan berbagai dokumen serta laporan-laporan yang diterbitkan oleh instansi terkait.

2. Studi lapangan yaitu pengumpulan data dimana penulis secara langsung ke obyek penelitian dengan menggunakan teknik penelitian sebagai berikut:

a. Observasi yaitu salah satu metode dalam pengumpulan data secara sengaja, terarah, sistematis dan terencana sesuai tujuan yang akan dicapai dengan mengamati keadaan ataupun seluruh kegiatan pembangunan.

b. Wawancara yaitu suatu metode dalam mengumpulkan data dengan cara tanya jawab dan dialog atau diskusi dengan informan.

\section{Teknik Analisis Data}

Efektivitas menggambarkan kemampuan Pemerintah Desa dalam merealisasi keuangan Alokasi Dana Desa untuk melaksanakan program yang direncanakan dibandingkan dengan target yang telah ditetapkan berdasarkan potensi nilai rill (Abbdul Halim, 2004). Untuk menjawab permasalahan digunakan analisis deskriptif kualitatif, dimana analisis ini merupakan proses penulisan yang menggunakan data deskriptif berupa kata-kata tertulis atau lisan dari orang-orang dan pelaku yang dapat diamati. 


\section{Definisi Operasional}

Untuk menjelaskan konsep dalam penelitian ini, maka definisi operasional dalam penelitian ini adalah sebagai berikut:

1. Perencanaan adalah musrembang desa untuk membahas rencana kegiatan penggunaan anggaran $\mathrm{ADD}$, diukur dengan jumlah dengan pihak yang berpartisipasi (hadir dan memberi saran), pokok bahasan dan hasil musrembang serta transparasi rencana kepada masyarakat.

2. Pelaksanaan adalah penyelesaian kegiatan yang telah direncanakan, diukur dengan jumlah pihak yang berpartisipasi (tenaga atau materi), transparansi informasi pelaksanaan pengelolaan alokasi dana desa atau kegiatan kepada masyarakat dan penyelesaian serta capaian tujuan kegiatan.

3. Pengawasan adalah bahwa rencana yang ditetapkan telah dilaksanakan sesuai dengan tujuan yang telah di tentukan.

4. Pembangunan fisik adalah segala bentuk perbaikan atau bentuk pembangunan infrastruktur yang dilakukan.

5. Pembangunan non fisik atau sosial adalah pembanguan sumber daya manusia, ekonomi, kesehatan, dan pendidikan atau pelatihan.

6. Efektivitas adalah penerimaan ADD melalui APBDes Di Desa Tegal Arum, Kecamatan Mranggen Kabupaten Demak yang di ukur dalam juta rupiah selama tahun.

\section{HASIL DAN PEMBAHASAN}

\section{Gambaran Umum Lokasi}

1. Kondisi Geografis

Kajian tulisan ini dilakukan di Desa Tegal Arum, Kecamatan Mranggen Kabupaten Demak, yang merupakan desa kecil dan perbatasan langsung dengan Kota Semarag. Karena letaknya yang strategis dan menjadi penyangga tenaga kerja di Kota Semarang. Desa 
Tegal Arum mempunyai wilayah $4 \mathrm{KM}^{2}$. Desa Tegal Arum terdiri dari 3 (tiga) perdukuhan yakni dukuh Ngumpul, dukuh Blado dan dukuh Ngaluran, jumlah RW 4 dan RT 20, sedangkan jumlah penduduk sebanyak 8.000 jiwa dengan tingkat kepadatan 1700Jiwa/KM.

\section{Keadaan Kantor Desa}

Dalam upaya untuk mencapai tujuan pembangunan desa secara efektif dan efisien kedudukan unsur pegawai Desa selaku sumber daya manusia (SDM) memegang peranan penting karena unsur pegawai merupakan pengelola utama segenap rencana dan program kerja organisasi yang akan dilaksanakan.

Efektivitas Pengelolaan Alokasi Dana Desa dalam meningkatkan pelaksanaan pembangunan pada Desa Pola Kecamatan Pasir Putih Kabupaten Muna

Pengelolaan ADD mulai di implementasikan di Indonesia pada tahun 2015 dengan dasar PP 72/2015 tentang desa yang kini telah di pertegas dengan lahirnya UU 6/2014 tentang desa. Aturan ini mewajibkan kepada pemerintah daerah kabupaten/kota untuk mengalokasikan dana transfer dari pusat dan di teruskan ke rekening desa yang dikenal dengan Alokasi Dana Desa (ADD).

\section{Perencanaan, Pengelolaan Alokasi Dana Desa}

Rencana Kerja Pembangunan Desa (RKPDes) dalam pengelolaan alokasi dana desa di bidang pembangunan fisik ada 3 program yaitu pembangunan betonisasi jalan desa, pembuatan sabuk irigasi dan pembangunan gapura desa. Sedangkan di bidang Pembangunan non fisik ada 5 program yaitu pelatihan kepala Desa dan perangkat, peningkatan kapasitas lembaga masyarakat, pembinaan pemuda dan olahraga, pembinaan organisasi PKK dan pemberdayaan lansia. Berikut hasil wawancara dengan Kepala Desa, mengenai program yang telah di rencanakan apakah dapat terialisasi semua yaitu sebagai berikut: "Program yang telah direncanakan dapat terialisasiakan semua dan partisipasi masyarakat dalam pembangunan fisik maupun pembangunan non fisik". (Wawancara, Januari 2019). 
2. Pelaksanaan Pengelolaan alokasi Dana

Jumlah ADD yang dialokasi pada Desa Tegal Arum, Kecamatan Mranggen Kabupaten Demak seperti pada tabel 2

Tabel 3

Alokasi Alokasi Anggaran Dana Desa

Desa Tegal Arum, Kecamatan Mranggen Kabupaten Demak

Tahun Anggaran 2018

\begin{tabular}{|c|c|c|c|}
\hline No & Nama Kegiatan & $\begin{array}{c}\text { Alokasi } \\
(\%)\end{array}$ & $\begin{array}{c}\text { Jumlah } \\
\text { (Rp) }\end{array}$ \\
\hline 1 & $\begin{array}{l}\text { Penyelenggaraan } \\
\text { Desa }\end{array}$ & $20 \%$ & 202.565 .000 \\
\hline 2 & Pelaksanaan Pembangunan Desa & $64 \%$ & 648.208 .000 \\
\hline 3 & Pemberdayaan Masyarakat & $10 \%$ & 101.282 .500 \\
\hline 4 & Pembinaan Masyarakat & $5 \%$ & 50.641 .250 \\
\hline 5 & Dana Cadangan & $1 \%$ & 10.128 .250 \\
\hline & Jumlah & $100 \%$ & 1.012 .825 .000 \\
\hline
\end{tabular}

Sumber : RKPDes Tegal Arum (2019)

Jika mengacu pada PP 47/2015 Ps 100 bahwa ketentuan penggunaan Belanja Desa $70 \%$ digunakan untuk mendanai penyelenggaraan pemerintahan Desa, pelaksanaan pembangunan Desa, pembinaan kemasyarakatan Desa, pemberdayaan masyarakat Desa, dan $30 \%$ digunakan untuk penghasilan tetap dan tunjangan kepala Desa dan perangkat Desa, operasional Pemerintah Desa, tunjangan dan operasional Badan Permusyawaratan Desa (BPD) dan insentif rukun tetangga dan rukun warga. Maka, dapat disimpulkan bahwa pelaksanaan pembangunan Desa di Desa Tegal Arum, Kecamatan Mranggen Kabupaten Demak telah sesuai dengan ketentuan yang berlaku. 


\section{KESIMPULAN DAN SARAN}

\section{Kesimpulan}

Musrembang desa yang diadakan pemerintah desa dan BPD dalam mengelola Alokasi Dana Desa sudah efektif, dimana dalam kegiatan musrembang partisipasi masyarakat cukup baik, dan sudah memenuhi keterwakilan dari berbagai lapisan yang ada di masyarakat, sehingga banyak usulan yang tidak tercover pada anggaran tahun berjalan dan diputuskan pada anggaran periode selajutnya, namun juga harus diperhitung kebutuhan masyarakat yang paling mendesak. Pelaksanaan program ADD sudah efektif, dimana penggunaan anggaran dapat terselesaikan dengan baik demikian pula dengan transparansi informasi tentang pelaksanaan perencanaan kegiatan oleh pemerintah desa kepada masyarakat, sehingga pencapaian tujuan pengelolaan Alokasi Dana Desa yang dilakukan dikategorikan efektif. Keefektifan dalam setiap tahapan Pengelolaan Alokasi Dana Desa tersebut sesuai dengan prinsip pengelolaan dan tujuan yang mengutamakan transparansi informasi, hal ini terjadi karena semua unsur lapisan masyarakat terlibat dalam setiap proses pengelolaan dana desa.

\section{Saran}

Berdasarkan uraian dalam kesimpulan maka saran yang diajukan adalah Sebagai Pemerintah Desa Tegal Arum, Kecamatan Mranggen Kabupaten Demak, dalam proses Pengelolaan Alokasi Dana Desa yang dimulai dari tahap perencanaan dan pelaksanaan, dalam melakukan kegiatan musrembang desa, seharusnya meningkatkan keterlibatkan masyarakat dan usulan kegiatan itu harus dari masyarakat yang tentukan di sesuaikan dengan kebutuhan prioritas masyarakat dalam musrembang dan transparansi informasi yang disampaikan oleh perangkat Desa kepada masyarakat dan pelaksanaan kegiatan harus melibatkan masyarakat serta transparansi informasi tentang penggunaan anggaran alokasi dana desa. 


\section{DAFTAR PUSTAKA}

Abdul Halim, 2004. Akuntansi Keuangan Daerah. Jakarta: Salemba Empat.

Abdul Halim, 2004. Manajemen Keuangan Daerah, Edisi Revisi, Yogyakarta: UPP AMP.

Adisasmita, R. (2006) Pembangunan Pendesaan dan Perkotaan. Yogyakarta: Graha Ilmu.

Adisasmita, S.A. (2011), Perencanaan Infrastruktur Transportasi Wilayah. Yogyakarta: Graha Ilmu.

Ahmadi, 2001. Ilmu Usaha Tani, Jakarta Penebar Swadaya.

Andi Mahmudi, 2005. Manajemen Kinerja Sektor Publik. Yogyakarta: UPP AMP YKPN.

Aprillia, 2014. Pembangunan Berbasis Masyarakat, Bandung: Alfabeta

Beratha, I Nyoman, 1992. Masyarakat Desa dan Pembangunan Desa. Jakarta: Ghalia Indonesia.

Devas, 1989, Keuangan Pemerintah Daerah di Indonesia, Jakarta: Universitas Indonesia.

Dunn, William, 2003. Analisis Kebijakan Publik. Yogyakarta: Gadjah Maja University Press.

Effendi Bachtiar, 2002. Pembangunan Desa Berwawasan Lingkungan. Jakarta: Bumi Aksara.

Gibson (dalam Hariss 2015) Perilaku Organisasi, Edisi 16, Jakarta.

Gie.The Liang, 2002, Administrasi Perkantoran Moderen. Yogyakarta: Liberty

Griffin, Ricky.W. 2004. Manajemen. Edisi 7 Jilid 2. Jakarta: Erlangga.

Handoko.T.Hani, 2000. Manejemen Sumber Daya Manusia. Yogyakarta: BPFE

Hasibuan, Malayu S. P. 2006, Manajemen Sumber Daya Manusia, Edisi Revisi: Jakarta. Bumi Aksara.

James L.Gibson, et.al, Organisasi dan Manajemen. Perilaku Struktur Proses, Alih Bahasa: Wahid, Djoerban, (Jakarta: Erlangga, 1995), hlm.26

Kartasasmita, Ginandjar, 2001. Rakyat Pembangunan Untuk: Memadukan Pertumbuhan Dan Pemerataan, Jakarta: Pustaka CIDESINDO

Manullung atik \& ratminto, 2012. Manajemen pelayanan, pustaka belajar. Yogyakarta: max saleleng.

Mardiasmo, 2004. Otonomi dan Manajemen Keuangan Daerah, Yogyakarta: 
Muntahanah, siti, Efektivitas Pengelolaan Alokasi Dana Desa di Kecamatan Somagede Kabupaten Banyumas. Jurnal Ekonomi.

Nafarin, 2000. Penggangaran Perusahaan. Edisi Pertama. Jakarta: Salemba Empat.

Nanang Fattah. 2004. Konsep Manajemen Berbasis Sekolah (MBS) dan Dewan Sekolah, Bandung: Pustaka Bani Quraisy.

Osborne dan Gaebler, 1997. Reinventing Government, Jakarta: Pustaka Binaman Pressindo.

Peraturan Menteri Dalam Negeri Nomor 37 Tahun 2007 tentang Pedoman Pengelolaan Keuangan Desa Pasal 18

Peraturan Pemerintah 6 Tahun 2014 Tentang Desa (c.72) Jakarta, Pemerintahan Negara Kesatuan Republik Indonesia.

Peraturan Pemerintah Nomor 72 Tahun 2005 pasal 1 ayat 11 huruf c.

Peraturan Pemerintah Republik Indonesia Nomor 72 Tahun 2005 Tentang Desa (c.72) Jakarta, Pemerintahan Negara Kesatuan Republik Indonesia.

Qalyubi Shyhabuddin. 2007. Manejemen Penelitian. Jakarta.

Rudianto, 2006.Akuntasi Manajemen: Informasi Untuk Pengambilan Keputusan Strategi. Jakarta: Grasindo.

S.P.Siagian, 1978. Manajemen, Yogyakarta.

Siagian, 2012, Administrasi Pembangunan. Jakarta: Haji Mas Agung.

Soemantri, 2011. Pedeoman Penyelenggara Pemerintah Desa, Bandung: Fokus Media

Sukanto, Azwardi, Efektivitas alokasi dana desa dan kemiskinan di Provinsi Sumatra utara, Junal Ekonomi Pembangunan.

Suksesi. 2007. Efektifitas Program Alokasi Dana Desa (ADD) Terhadap Perekonomian Desa di Kabupaten Pacitan. Dikutip dalam http://journalfe.unitomo.ac.id./wp.

Suparno. 2001. Membangunan Kompetensi Belajar. Direktorat Jendral Pendidikan Tinggi Departemen Pendidikan Nasional.

Sutrisno, 2007. Manajemen Keuangan, Yogyakarta: Ekonesia.

Terry, George dan Leslie W. Rue, 2010. Dasar-dasar Manajemen. Cetakan.11. Jakarta: PT. Bumi Aksara

Tjokroamidjojo, 1995. Perencanaan Pembangunan. Jakarta: Haji Mas Agung. 
Todaro Micheal, 2000. Pembnagunan Ekonomi 2. Edisi Kelima, Jakarta: PT Bumi Aksara.

Todaro Michel, 2000. Pembangunan Ekonomi di Dunia ke Tiga, Jakarta: Erlangga.

Undang-Undang Republik Indonesia Nomor 32 Tahun 2004 Tentang Pemerintahan Daerah (c.1) Jakarta, Direktorat Jendral Otonomi Daerah.

Welsch, Hilton, Gordon. 2000. Anggaran Perencanaan dan Pengendalian Laba. Diterjemahkan oleh Purwatiningsi dan Maudy warouw. Buku Satu. Jakarta: Salemba Empat.

Widjaja, Haw. 2003. Otonomi Desa. Jakarta: PT Raja Grafindo Persada.

Wijayanti, Irine Diana Sari, 2008. Manajemen, Yogyakarta: Mitra Cendikia Press. 
Majalah Ilmiah Solusi

Vol. 17, No. 3 Juli 2019

ISSN : 1412-5331

Halaman ini sengaja dikosongkan 